\section{Cardiac output in Paget's disease: response to long-term salmon calcitonin therapy}

Paget's disease is accompanied by an increase in the vascularity and flow of blood through bone. With sufficiently severe disease the peripheral vascular resistance decreases and the cardiac output (CO) increases above normal levels, either at rest or after exercise. ${ }^{1}$ In some patients high-output congestive cardiac failure may be seen. As in patients with arteriovenous fistulae, the oxygen saturation of venous blood is increased and early venous filling occurs during arteriography. Anatomical arteriovenous shunts, however, have not been demonstrated in Paget's disease, and the increased venous oxygen saturation probably results from a rapid flow of blood through an enormously dilated capillary bed. ${ }^{2}$ Long-term treatment of Paget's disease with calcitonin reduces the abnormally raised turnover of bone and sometimes produces radiological healing of the disease. ${ }^{3} \mathrm{We}$ therefore investigated the possibility that calcitonin treatment will, in addition, reduce the bone vascularity and thus lower the $\mathrm{CO}$.

\section{Patients, methods, and results}

Six patients with symptomatic Paget's disease were studied before and during treatment with salmon calcitonin $50 \mathrm{MRC}$ units (about $12.5 \mu \mathrm{g}$ ) twice daily subcutaneously (Calsynar). At least 4 daily urine collections were obtained for total hydroxyproline assay at $0,3,9,12$, and 15 months of treatment. On each occasion the $\mathrm{CO}$ was measured under standard conditions by the indicator dilution technique (iodinated ${ }^{125} I$ ) human serum albumin $B P$ ). Indicator dilution curves were constructed from the raw data using a Fortran Program and CDC 1800 computer to calculate the CO value. The central venous oxygen saturation was calculated from the oxygen uptake, $\mathrm{CO}$, haemoglobin concentration, and arterial oxygen content. ${ }^{5}$

The CO was initially raised in 4 of the six patients and fell progressively in 3 of them during treatment with salmon calcitonin (see table). A simultaneous fall in the oxygen saturation of mixed venous blood was also observed, suggesting a reduction in bone blood flow and a rise in peripheral vascular resistance. This is supported by the observed fall in exercise-induced $\mathrm{CO}$ in the one patient studied. The fourth patient with a raised $\mathrm{CO}$ had radiologically extensive and biochemically the most active disease in the whole group. Despite this the haemodynamic disturbance was relatively modest, suggesting that there may be considerable variation in the vascular abnormalities accompanying Paget's disease in different patients. ${ }^{5}$ Treatment produced a noticeable reduction in bone turnover (hydroxyproline excretion), as in all the other patients, but no fall in CO. Treatment would probably need to be prolonged to produce a fall in $\mathrm{CO}$ in this and similarly affected patients. As might have been expected, no change in $\mathrm{CO}$ occurred during treatment in the two patients whose values remained in the normal range throughout. Pain relief was claimed by all the affected patients within a few weeks of starting treatment, and in cases 1,3 , and 5 the patients managed without daily analgesia for the first time in 12 months.

\section{Comment}

These results confirm the effectiveness of calcitonin treatment in Paget's disease. $^{3}$ We conclude that long-term calcitonin treatment may also be of clinical value in patients with high output congestive cardiac failure and, furthermore, that the increased vascularity in Paget's disease arises as a secondary response to the abnormal increase in bone cell activity and is not an integral part of the disease process.

We thank Professor J Anderson and Dr C G McKerron, P Hugh-Jones, and V Parsons for allowing us to study their patients and for the facilities provided; the Arthritis and Rheumatism Council and the Armour Pharmaceutical Company for providing generous financial support (NJYW); and nurses $\mathrm{K}$ Kuester and A McSwaine and Miss M Rusbridge for their invaluable assistance.

${ }^{1}$ Lequime, J, and Denolin, H, Circulation, 1955, 12, 215.

2 Rhodes, B A, et al, New England fournal of Medicine, 1972, 287, 686.

${ }^{3}$ Woodhouse, N J Y, British Fournal of Hospital Medicine, 1974, 2, 677.

${ }^{4}$ Kivirikko, K I, Latinen, O, and Prockop, D H, Analytical Biochemistry, 1967, 19, 249.

${ }^{5}$ Crosbie, W A, Mohamedally, S M, and Woodhouse, N J Y, Clinical Science and Molecular Medicine, 1975, 48, 537.

Medical and Chest Units, King's College Hospital Medical School, London SE5

N J Y WOODHOUSE, MRCP, honorary senior lecturer

W A CROSBIE, MRCP, senior lecturer

S M MOHAMEDALLY, MPHIL, FRSH, research fellow

Details of 6 patients with Paget's disease before and during treatment with salmon calcitonin. CO in case 1 was $4 \cdot 84 l /$ min $^{1} \mathrm{~m}^{2}$ in 1960

\begin{tabular}{|c|c|c|c|c|c|c|c|c|}
\hline Case no & $\underset{\text { (years) }}{\text { Age }}$ & Sex & $\begin{array}{l}\text { Surface area } \\
\left(\mathrm{m}^{2}\right)\end{array}$ & ${ }_{1 \mathrm{~min}^{-1} \mathrm{~m}^{-2}}^{\mathrm{CO}}$ & $\underset{(\mathrm{mg} / \mathrm{d})}{\text { OH-Pro }}$ & $\begin{array}{l}\mathrm{Svo}_{2} \\
(\%)\end{array}$ & Bone pain & $\begin{array}{c}\text { Duration of } \\
\text { treatment } \\
\text { (months) }\end{array}$ \\
\hline 1 & 52 & $\mathrm{~F}$ & $\begin{array}{l}1 \cdot 26 \\
1 \cdot 24 \\
1 \cdot 24\end{array}$ & $\begin{array}{r}11 \cdot 90 \\
5.32 \\
3.55\end{array}$ & $\begin{array}{r}467 \\
218 \\
60\end{array}$ & $\begin{array}{l}88.2 \\
78.8 \\
72 \cdot 4\end{array}$ & $\begin{array}{c}+++ \\
+ \\
+\end{array}$ & $\begin{array}{r}0 \\
3 \\
15\end{array}$ \\
\hline 2 & 68 & $M$ & $\begin{array}{l}1.91 \\
1.91 \\
1.91\end{array}$ & $\begin{array}{c}6 \cdot 18 \\
5 \cdot 65^{*} \cdot 9 \cdot 00 \dagger \\
3 \cdot 92 * 7 \cdot 43 \dagger\end{array}$ & $\begin{array}{r}191 \\
82 \\
44\end{array}$ & $\begin{array}{l}81 \cdot 2 \\
70 \cdot 2 \\
69 \cdot 8\end{array}$ & \pm & $\begin{array}{l}0 \\
3 \\
9\end{array}$ \\
\hline 3 & 74 & $\mathrm{M}$ & $\begin{array}{l}1.65 \\
1.66 \\
1.66\end{array}$ & $\begin{array}{l}3.63 \\
4.04 \\
3.97\end{array}$ & $\begin{array}{l}894 \\
237 \\
159\end{array}$ & $\begin{array}{l}70.0 \\
76.00 \\
74.8\end{array}$ & $\equiv$ & $\begin{array}{r}0 \\
3 \\
12\end{array}$ \\
\hline 4 & 68 & $\mathbf{M}$ & $\begin{array}{l}1.82 \\
1.86 \\
1.77\end{array}$ & $\begin{array}{l}3.40 \\
3.22 \\
2 \cdot 20\end{array}$ & $\begin{array}{r}103 \\
32 \\
35\end{array}$ & $\begin{array}{l}74 \cdot 4 \\
73 \cdot 4 \\
64 \cdot 3\end{array}$ & \pm & $\begin{array}{l}0 \\
3 \\
9\end{array}$ \\
\hline 5 & 68 & $\mathbf{F}$ & $\begin{array}{l}1.61 \\
1.58 \\
1.58\end{array}$ & $\begin{array}{l}2 \cdot 79 \\
2 \cdot 47 \\
2 \cdot 47\end{array}$ & $\begin{array}{r}113 \\
37 \\
35\end{array}$ & $\begin{array}{l}65.0 \\
60.6 \\
69.6\end{array}$ & + \pm+ & $\begin{array}{r}0 \\
3 \\
12\end{array}$ \\
\hline 6 & 75 & $\mathrm{~F}$ & $\begin{array}{l}1.45 \\
1.45 \\
1.48 \\
\end{array}$ & $\begin{array}{l}2 \cdot 69 \\
2.69 \\
2 \cdot 63 \\
\end{array}$ & $\begin{array}{l}40 \\
24 \\
33 \\
\end{array}$ & $\begin{array}{l}61 \cdot 7 \\
73.4 \\
58 \cdot 5 \\
\end{array}$ & \pm & $\begin{array}{r}0 \\
3 \\
15 \\
\end{array}$ \\
\hline Normal range & & & & $2 \cdot 28-2 \cdot 88$ & $15-45$ & & & \\
\hline
\end{tabular}

